\title{
Oceanography
}

CITATION

Abbott, M.R. 2014. From the President: Seeking new partners to sustain and enrich our future.

Oceanography 27(2):8-9, http://dx.doi.org/10.5670/oceanog.2014.54.

$\mathrm{DOI}$

http://dx.doi.org/10.5670/oceanog.2014.54

COPYRIGHT

This article has been published in Oceanography, Volume 27, Number 2, a quarterly journal of The Oceanography Society. Copyright 2014 by The Oceanography Society. All rights reserved.

USAGE

Permission is granted to copy this article for use in teaching and research. Republication, systematic reproduction, or collective redistribution of any portion of this article by photocopy machine, reposting, or other means is permitted only with the approval of The Oceanography Society. Send all correspondence to: info@tos.org or The Oceanography Society, PO Box 1931, Rockville, MD 20849-1931, USA. 


\section{Seeking New Partners to Sustain and Enrich Our Future}

Private philanthropy has played an important role in the development of oceanography in the United States. From the engagement of the Scripps family in the establishment of the Marine Biological Association of San Diego in 1905 to a grant from the Rockefeller Foundation that led to the creation of the Woods Hole Oceanographic Institution in 1930, private gifts and donations helped nurture the growth of a new scientific endeavor. As with today's philanthropy, many donors were actively engaged in the decisions and programs of the new institutions while other donors were content to give unrestricted gifts for the institution's leaders to use as they saw fit. For example, Florence Corliss Lamont, the widow of Wall Street banker Thomas Lamont, gave property as an unrestricted gift to Columbia University, whose officials decided to use the property to create a geological research institute. On the other hand, members of the Scripps family were active in the formation and promotion of the marine laboratory that eventually became the Scripps Institution of Oceanography.

Over the last 60 years, oceanography has grown substantially, primarily because of the expansion of federal support for the nation's research and development $(R \& D)$ enterprise. Although $R \& D$ in the private sector is substantially larger than the federal $R \& D$ budget, most university-based R\&D is funded by the federal government. However, the slowing down (and at some agencies, reduction) of the federal R\&D budget is leading to a growing unease in our US institutions. The "decadal survey" of ocean sciences now underway at the National Research Council is one example of how the community is responding to a constrained budget.
Another response is in a sense a return to our roots - the cultivation of private philanthropy. A recent article entitled "Billionaires with Big Ideas are Privatizing American Science" by William Broad of the New York Times (March 15, 2014) reported on this new generation of large philanthropic ventures. Interestingly, many of these new ventures are in the ocean sciences. The article notes that much of this new funding is being used to fill in the gaps in the traditional funding sources, for example, in areas that are high risk or require large amounts of funding over long time periods. The amount of funding is significant, and although it does not replace federal funding, it is viewed as an important source by many institutions and scientists.

Baker, Schmitt, and Wunsch (2007) wrote in Oceanography about the need for a new endowment to support long-term ocean observations, an endeavor at the intersection of science and technology that has long struggled to obtain sustained funding. They suggested that a $\$ 1$ billion endowment would be sufficient to sustain an institute that would conduct both science and long-term measurements. Although such an endowment is well within the scope of private philanthropy, Broad's article notes that today's philanthropists tend to have very specific objectives in mind, such as curing a specific disease or solving a difficult environmental problem. They tend not to fund basic $R \& D$ or open-ended studies such as climate observations. Moreover, there is a tendency to fund existing (and prestigious) institutions such that "rich" institutions become richer. Private philanthropy is not a panacea for the stagnation of federal R\&D funding; it brings its own set of opportunities and constraints. 


\section{Please Contribute to the New Student and Early Career Funds}

Seeking out new partners, be they private donors and foundations or new government agencies that have not traditionally funded oceanography, is a worthy task. However, we also need to consider the demand side as well as the supply side. Alberts et al. (2014) surveyed biomedical research in the United States, noting that over 40,000 postdoctoral researchers are presently employed with little chance of ever obtaining a faculty position. They recommend several structural changes, including managing the size of the graduate student population and expanding those students' career pathways by providing broader training, increasing postdoctoral salaries and limiting their time of support, and reducing reliance on soft-money faculty positions. Although the scope of the problem is substantially larger in biomedical research, oceanography is facing many of the same issues. As I wrote in the March 2014 issue, let's continue the discussion, especially in the training of our graduate students. Please send your thoughts to magazine@tos.org.



MARK R. ABBOTT, TOS PRESIDENT

\section{REFERENCES}

Alberts, B., M.W. Kirschner, S. Tilghman, and H. Varmus. 2014. Rescuing US biomedical research from its systemic flaws. Proceedings of the National Academy of Sciences of the United States of America 111:5,773-5,777, http://dx.doi.org/10.1073/ pnas. 1404402111.

Baker, D.J., R.W. Schmitt, and C. Wunsch. 2007. Endowments and new institutions for long-term observations, Oceanography 20(4):10-14, http://dx.doi.org/10.5670/ oceanog.2007.19.
Building upon the successful activities held during the 2014 Ocean Sciences Meeting, TOS has created a simple tool to accept donations to the newly established Student and Early Career Funds. The Student Fund supports student mentoring programs and other TOS-related activities, and the Early Career Fund supports early career scientist participation at professional meetings or travel to meet with a mentor. Please look for the "Donate" button at the top of the TOS website (www.tos.org) to lead you to the donation page.

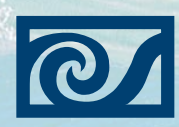

\section{THE OCEANOGRAPHY SOCIETY}

\section{REGULAR ISSUE FEATURES}

The editorial staff encourages unsolicited manuscripts on oceanography themes for consideration and publication under the Regular Features banner. Please see our Author Guidelines (http://tos.org/oceanography/ guidelines.html) for more information about manuscript submission.

\section{SPECIAL ISSUES}

Vol 27 | No 3 | Sep 2014
Navy Operational Models
Vol 27 | No 4 | Dec 2014
Fisheries Oceanography
Vol 28 | No 1 | Mar 2015
Salinity Processes in the Upper
Ocean Regional Study (SPURS)
Experiment

Vol 28 | No 2 | Jun 2015 Emerging Themes in Ocean Acidification Science

Vol 28 | No 3 | Sep 2015 Russian American Long-Term Census of the Pacific Arctic

Vol 28 | No 4 | Dec 2015 Western Boundary Currents (tentative) 